\title{
Enhanced Ferroelectric Properties of Multilayer SBT-BTN Thin Films for NVRAM Applications
}

\author{
Oleksandr Khorkhordin, Chia-Pin Yeh, Bodo Kalkofen, Edmund Burte \\ Institute of Micro and Sensor Systems, Otto von Guericke University, Magdeburg, Germany \\ Email: khorkhordin@web.de
}

Received 31 August 2015; accepted 27 September 2015; published 30 September 2015

Copyright (C) 2015 by authors and Scientific Research Publishing Inc.

This work is licensed under the Creative Commons Attribution International License (CC BY). http://creativecommons.org/licenses/by/4.0/

(c) (i) Open Access

\begin{abstract}
Ferroelectric $\mathrm{SrBi}_{2} \mathrm{Ta}_{2} \mathrm{O}_{9}-\left(\mathrm{Bi}_{4} \mathrm{Ti}_{3}\right)_{1-x} \mathrm{Nb}_{x} \mathrm{O}_{12}(x=0.02)$ (SBT-BTN) multilayer thin films with various stacking periodicity have been synthesized on $\mathrm{Ir} / \mathrm{Ti} / \mathrm{SiO}_{2} / \mathrm{Si}$ substrate by metal organic chemical vapor deposition technique (MOCVD). Tributylbismuth $\left[\mathrm{Bi}\left(\mathrm{C}_{4} \mathrm{H}_{9}\right)_{3}\right]$, Strontium-bis[Tantal(pentanethoxy)(2-methoxyethoxid)] [ $\mathrm{Sr}\left[\mathrm{Ta}(\mathrm{OEt})_{5}\left(\mathrm{OC}_{2} \mathrm{H}_{4} \mathrm{OMe}\right)\right]_{2}$ ], Titanium Bis(isopropoxy)bis(1-methoxy2-methyl-2-propoxide) $\left[\mathrm{Ti}(\mathrm{OiPr})_{2}(\mathrm{mmp})_{2}\right]$ and Niob-ethoxide $\left[\mathrm{Nb}_{(}\left(\mathrm{OC}_{2} \mathrm{H}_{5}\right)_{5}\right]$ were selected as precursors. X-ray diffraction patterns show that the multilayer films annealed at $800^{\circ} \mathrm{C}$ consist of fully formed perovskite phase with polycrystalline structure and plate-like grains with no crack. The remanent polarization (2.Pr) and coercive field (Ec) are $16.2 \mu \mathrm{C} / \mathrm{cm}^{2}$ and $230 \mathrm{kV} / \mathrm{cm}$, respectively, which is much higher, compared to pure SBT film $\left(2 \cdot \mathrm{Pr}=6.4 \mu \mathrm{C} / \mathrm{cm}^{2}, \mathrm{Ec}=154 \mathrm{kV} / \mathrm{cm}\right)$. In the films prepared above $700^{\circ} \mathrm{C}$, postannealing increased the capacitor shorting rate; this was attributed to oxidizing of the top iridium layer. In this paper, the dependence of composition variation around stoichiometric on ferroelectric properties in SBT-BTN multilayer films is studied.
\end{abstract}

\section{Keywords}

Ferroelectric, SBT, BTN, MOCVD, Multilayer

\section{Introduction}

Aurivillius-type structure compounds have been widely investigated by their use in non-volatile ferroelectric memories (NVMs) where they are prepared as thin films [1] [2]. Recently, bismuth-layered-structure ferroelectric materials (BLSF), such as $\mathrm{Bi}_{4} \mathrm{Ti}_{3} \mathrm{O}_{12}$ (BIT) and $\mathrm{SrBi}_{2} \mathrm{Ta}_{2} \mathrm{O}_{9}$ (SBT), and different ions substitutions have been studied to improve their fatigue, ferroelectric properties and possibly low polarization switching voltage. In or- 
der to improve their ferroelectric properties, the substitution technique, called "site engineering", was adopted from [3].

In a previous work, Park [2] found that $\mathrm{Bi}_{3.25} \mathrm{La}_{0.75} \mathrm{Ti}_{3} \mathrm{O}_{12}$ (BLT) thin film annealed at $650^{\circ} \mathrm{C}$ exhibited a large remanent polarization $\mathrm{P}_{\mathrm{r}}=12 \mu \mathrm{C} / \mathrm{cm}^{2}$. It was found that Nd doping of BIT film led to increased $\mathrm{P}_{\mathrm{r}}$ value of 25 $\mu \mathrm{C} / \mathrm{cm}^{2}$ due to decrease in oxygen vacancy concentration [4] [5]. Noguchi [6] pointed out that enhancement of remanent polarization was achieved when $\mathrm{Ti}^{4+}$ ions in $\mathrm{BiT}$ were replaced by ions with higher valences (e.g. $\mathrm{V}^{5+}$ and $\mathrm{W}^{5+}$ ). Shulman [7] and Villegas [8] reported reduction of conductivity of these films by doping with $\mathrm{Nb}$ or W. Such structures as $\mathrm{Bi}_{4} \mathrm{Ti}_{3} \mathrm{O}_{12}-\mathrm{SrBi}_{2} \mathrm{Ti}_{2} \mathrm{O}_{15}$ (BIT-SBT), $\mathrm{Bi}_{3} \mathrm{TiNbO}_{9}-\mathrm{Bi}_{4} \mathrm{Ti}_{3} \mathrm{O}_{12}$ (BTN-BIT), $\mathrm{Bi}_{2} \mathrm{MoO}_{6}-\mathrm{Bi}_{3} \mathrm{TiNbO}_{9}$ (BM-BTN) and $\mathrm{Bi}_{2} \mathrm{WO}_{6}-\mathrm{Bi}_{3} \mathrm{TiNbO}_{9}(\mathrm{BW}-\mathrm{BTN})$ have attracted further interest due to their artificially enhanced dielectric, ferroelectric and pyroelectric properties [9]-[14]. Ortega [15] showed dramatically increased remanent polarization $\left(\sim 20.8 \mu \mathrm{C} / \mathrm{cm}^{2}\right)$ and dielectric constant $(\sim 373)$ in bilayered (SBT/SBN) structures.

All these works suggest that substitution is an effective way to improve the ferroelectric property. Although perovskite type thin films SBT, BIT, and BTN have been extensively studied, no work on multilayer SBT and $\mathrm{Nb}^{5+}$-substituted BiT (BTN) thin films has yet been carried out. Therefore, we deposited SBT/BTN multilayer thin films with different stacking periodicities utilizing metal organic chemical vapor deposition process (MOCVD), optimized in our previous work [16]-[18].

MOCVD methods are widely used because they show advantages, such as simple injection system, superior step coverage, high deposition rate and composition uniformity over a large area compared to other techniques like pulsed laser deposition (PLD) [19] [20], metal-organic decomposition (MOD) and sol-gel (SG) [21]-[23].

In this paper, the MOCVD synthesis and characterization of multilayered SBT/BTN thin films on (111)Ir/ $\mathrm{Ti} / \mathrm{SiO}_{2} /(100) \mathrm{Si}$ substrates in a single-wafer reactor are reported.

\section{Methods}

The $\mathrm{Bi}_{4-x / 3} \mathrm{Ti}_{3-x} \mathrm{Nb}_{x} \mathrm{O}_{12}$ (BTN) $(x=0.02)$ and $\mathrm{SrBi}_{2} \mathrm{Ta}_{2} \mathrm{O}_{9}$ layer stacks were deposited by MOCVD reactor with liquid delivery system on $150 \mathrm{~mm}$ silicon wafers.10nm Ti and thereafter $100 \mathrm{~nm}$ Ir were deposited on $\mathrm{SiO}_{2}$ as bottom electrode by e-beam vaporizer. Tributylbismuth $\left[\mathrm{Bi}\left(\mathrm{C}_{4} \mathrm{H}_{9}\right)_{3}\right]$, Strontium-bis[Tantal(pentan-ethoxy)(2methoxyethoxid)] $\left[\mathrm{Sr}\left[\mathrm{Ta}(\mathrm{OEt})_{5}\left(\mathrm{OC}_{2} \mathrm{H}_{4} \mathrm{OMe}\right)\right]_{2}\right]$, Titanium Bis(isopropoxy)bis(1-methoxy-2-methyl-2-propoxide) $\left[\mathrm{Ti}(\mathrm{OiPr})_{2}(\mathrm{mmp})_{2}\right]$ and Niob-ethoxide $\left[\mathrm{Nb}\left(\mathrm{OC}_{2} \mathrm{H}_{5}\right)_{5}\right]$ were selected as precursors. Sr-Ta, Bi and Ti precursors were dissolved in octane of $0.02 \mathrm{~mole} / \mathrm{L}$ concentration, $\mathrm{Nb}$ was dissolved of $0.005 \mathrm{~mole} / \mathrm{L}$ concentration. Previously we reported the application of these precursors for SBT films deposition [17] [24] [25]. The process temperature was varied from $400^{\circ} \mathrm{C}$ to $550^{\circ} \mathrm{C}$, the pressure in the chamber was kept at about $5.0 \mathrm{mbar}$. The deposition rate of the BTN was about $\sim 50 \mathrm{~nm} / \mathrm{h}$, of SBT $\sim 100 \mathrm{~nm} / \mathrm{h}$ at $450^{\circ} \mathrm{C}$ and 5 bar chamber pressure. The oxygen to nitrogen ratio in a chamber was set to $3: 2$ and 3:4 for BTN and SBT deposition, respectively.

The prepared layer stacks are shown schematically in Figure 1. The multilayer M2-A and M3-A follow the same sequence as M2-B (BTN/SBT) except that BTN is interchanged with SBT and vice versa.

The thickness of the deposited SBT-BTN-SBT, BTN-SBT and SBT-BTN layers was in the range of $150-250$ $\mathrm{nm}$. The metal-ferroelectric-metal (MFM) capacitors were fabricated by deposition $0.2-1 \mathrm{~mm}$ square top electrodes using PVD through a shadow mask. The films were annealed in atmosphere for 30 minutes at the several different temperatures for final crystallization. The film thickness was measured on a spectroscopic ellipsometer in the spectral range of $280-780 \mathrm{~nm}$ in $10 \mathrm{~nm}$ steps. The polarization versus electric field (P-E) hysteresis measurements were performed using a ferroelectric test module TF ANALYZER 1000 (aixACCT Systems GmbH). Results for SBT films are discussed with the precursor solution compositions expressed as $x / y / 2$, where $x$ and $y$ represent the $\mathrm{Sr}$ and $\mathrm{Bi}$ atomic atomic contents, respectively, normalized with the Ta content fixed at 2 . The phase formation and crystallographic orientation of the films were characterized by X-ray diffraction (XRD) using $\mathrm{Cu}-\mathrm{K} \alpha$ radiation, the chemical composition of the films was analyzed with X-ray photoelectron spectroscopy (XPS).

\section{Results and Discussion}

The relationship between process parameter and composition of SBT films has been studied in previous work of our group [16]-[18] [24]. The XPS measurements of SBT and BTN films indicated an atomic composition of these films at various processing parameters. The BTN films with various $\mathrm{Ti} / \mathrm{Bi}$ mole ratios were deposited at $450^{\circ} \mathrm{C}$ by changing the input mass flow of $\mathrm{Ti}(\mathrm{OiPr})_{2}(\mathrm{mmp})_{2}$ to $\mathrm{Bi}\left(\mathrm{C}_{4} \mathrm{H}_{9}\right)_{3}$ vapors (Figure 2(a)). As the mass flow 


\begin{tabular}{|c|}
\hline SBT $100 \mathrm{~nm}$ \\
\hline BTN $50 \mathrm{~nm}$ \\
\hline SBT $100 \mathrm{~nm}$ \\
\hline Ir Tio $\mathrm{sio}$ Isi \\
\hline
\end{tabular}

(a)

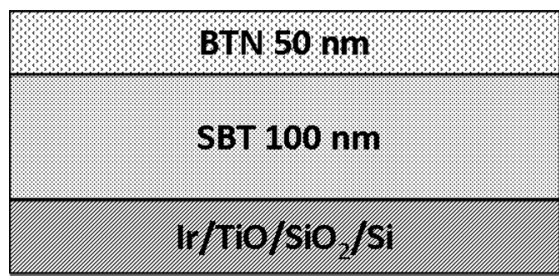

(b)

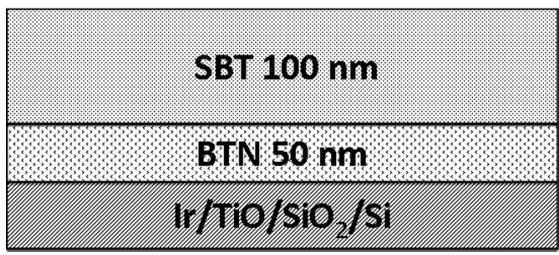

(c)

Figure 1. Schematic diagrams of multilayer thin films: (a) M-3A; (b) M2-A; (c) M2-B.

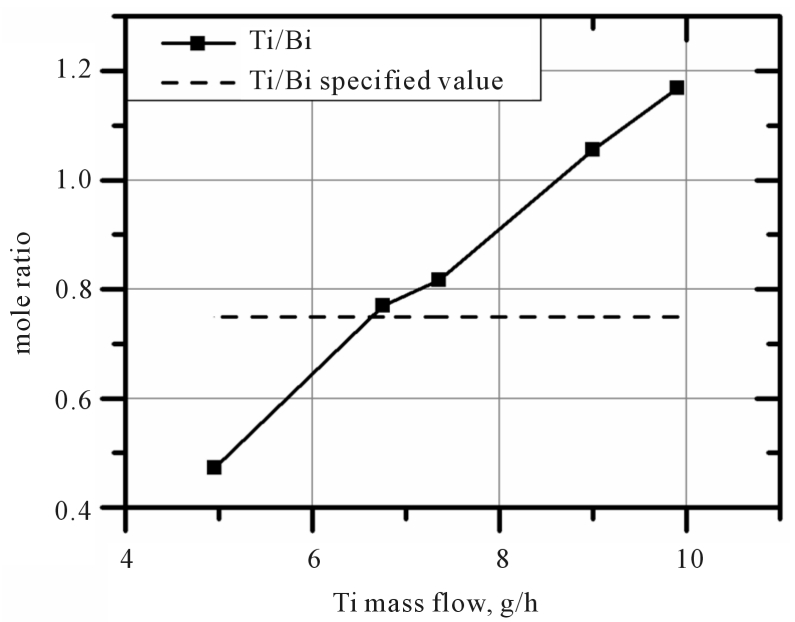

(a)

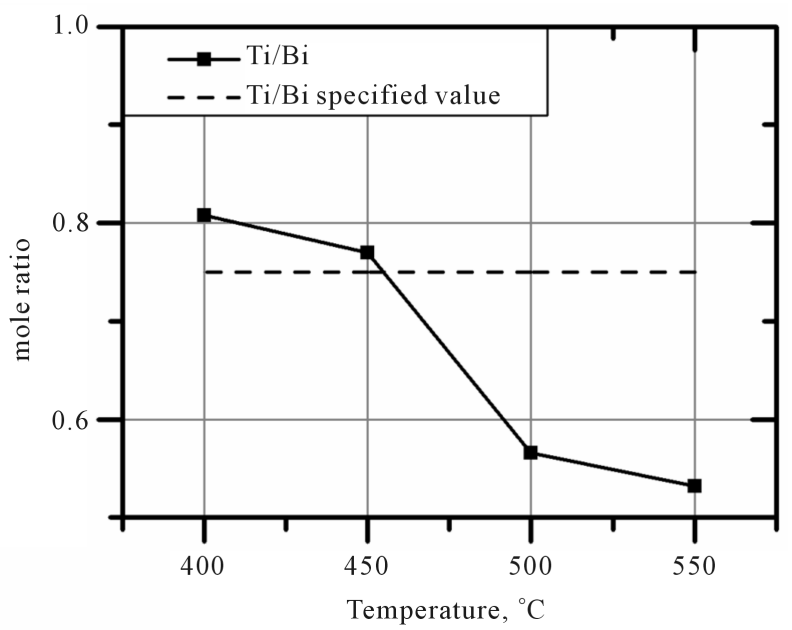

(b)

Figure 2. Ti/Bi mole ratio of BNT thin films as a function of (a) the Ti mass flow and (b) substrate temperature. 
ratio of Ti precursor increased from $2 \mathrm{~g} / \mathrm{h}$ to $10 \mathrm{~g} / \mathrm{h}, \mathrm{Ti} / \mathrm{Bi}$ ratio went up all the way, while temperature increase from $400^{\circ} \mathrm{C}$ to $550^{\circ} \mathrm{C}$ reduced $\mathrm{Ti} / \mathrm{Bi}$ ratio in the film from 0.88 to 0.53 respectively (Figure 2(b)). By Ti mass flow of $\sim 6.6 \mathrm{~g} / \mathrm{h}$ and process temperature of $450^{\circ} \mathrm{C}$ nearly stoichiometric composition $\left(\mathrm{Bi}_{4.17} \mathrm{Ti}_{2.98} \mathrm{Nb}_{0.02} \mathrm{O}_{12 \pm x}\right)$ can be obtained.

Figure 3 shows $\mathrm{Nb} / \mathrm{Ti}$ mole ratio in the BTN films as a function of $\mathrm{Nb}$ mass flow. It was shown in previous work by Song [26], that in BTN film $\mathrm{P}_{\mathrm{r}}$ rises with increasing $\mathrm{Nb}$ content to reach a maximum at a $\mathrm{Nb}$ content of about 0.02 . In our experiments it was unable to detect $\mathrm{Nb}$ in XPS spectrum as long as $\mathrm{Nb}$-mass flow was below $\sim 7.5 \mathrm{~g} / \mathrm{h}$. As $\mathrm{Nb}$ mass flow reached $7.5 \mathrm{~g} / \mathrm{h}$, we observed a small Nb-doublet in a XPS survey at $\sim 208 \mathrm{eV}$, which corresponds $2.3 \mathrm{Nb}$ at \% in the film. It was noted that BTN thin film has higher $\mathrm{P}_{\mathrm{r}}$ value of $4.9 \mu \mathrm{C} / \mathrm{cm}^{2}$ than BiT without $\mathrm{Nb}^{5+}$ doping $\left(\sim 1.8 \mu \mathrm{C} / \mathrm{cm}^{2}\right)$.

Figure 4(a) shows $\mathrm{Sr} / \mathrm{Ta}$ and $\mathrm{Bi} / \mathrm{Ta}$ mole ratios in the $\mathrm{SBT}$ films deposited by changing the input gas flow of $\mathrm{Bi}\left(\mathrm{C}_{4} \mathrm{H}_{9}\right)_{3}$ to $\mathrm{Sr}\left[\mathrm{Ta}(\mathrm{OEt})_{5}\left(\mathrm{OC}_{2} \mathrm{H}_{4} \mathrm{OMe}\right)\right]_{2}$ vapors. As chamber temperature increased, Bi/Ta slightly increased, while $\mathrm{Sr} / \mathrm{Ta}$ versus temperature was almost unchanged (Figure 4(b)). By Sr-Ta mass flow of $\sim 5.4 \mathrm{~g} / \mathrm{h}$ and process temperature of $450^{\circ} \mathrm{C}$ nearly stoichiometric composition in sense of $\mathrm{Bi}$ content $\left(\mathrm{Sr}_{0.58} \mathrm{Bi}_{2.04} \mathrm{Ta}_{2} \mathrm{O}_{9 \pm x}\right.$ as determined by XPS) can be obtained. However $\mathrm{Sr} / \mathrm{Ta}$ ratio was below stoichiometric, it was reported by $\mathrm{Li}$ [27] that $\mathrm{Sr}$ deficient films $\left(\mathrm{Sr}_{0.8} \mathrm{Bi}_{2.2} \mathrm{Ta}_{2} \mathrm{O}_{9 \pm x}\right)$ yield higher remanent polarization than stoichiometric films $\left(\mathrm{SrBi}_{2} \mathrm{Ta}_{2} \mathrm{O}_{9}\right)$, because of partial substitution of $\mathrm{Bi}$ for $\mathrm{Sr}$ ions results in the increase in 'rattling space'. On the other hand, as Bi concentration drops below stoichiometric in $\mathrm{Sr}$ deficient films, the exchange between $\mathrm{Sr}$ and Bi causes the serious degradation of the ferroelectric properties, also reported by $\mathrm{Li}$ [27] and Boyle [28].

Polarization-electric field (P-E) hysteresis loops were measured to examine the effect of Bi deficiency on the degradation of the ferroelectric properties in SBT films (shown in Table 1) under a maximum electric field of $500 \mathrm{kV} / \mathrm{cm}$. As the Bi content decrease from 2.2 to $1.3,2 \cdot \mathrm{P}_{\mathrm{r}}$ drops from $7.4 \mu \mathrm{C} / \mathrm{cm}^{2}$ to $2.3 \mu \mathrm{C} / \mathrm{cm}^{2}$ respectively.

After successful depositing of single SBT and BTN films, multilayer stack was deposited alternating SBT and BTN layers (Figure 1). Figure 5 shows the XRD patterns of single SBT, bilayer M2-A, M2-B and multilayer $\mathrm{M} 3-\mathrm{A}$ thins films annealed at $800^{\circ} \mathrm{C}$ for $30 \mathrm{~min}$ in atmosphere. The constituent phase and the orientation of the SBT-BTN, SBT-BTN-SBT and BTN-SBT films were identified by X-ray diffraction (XRD) using Cu-K $\alpha$ radiation to distinguish the SBT, BIT and BTN phases, pyrochlore and fluorite phases. Pyrochlore and fluorite phases are contamination phases in the $\mathrm{Sr}-\mathrm{Bi}-\mathrm{Ta}-\mathrm{O}$ and $\mathrm{Bi}-\mathrm{Ti}-\mathrm{Nb}-\mathrm{O}$ system. It was ascertained that the ferroelectricity was hardly observed when the films was heat treated below $750^{\circ} \mathrm{C}$. As the annealing temperature increase, annealing results in sharp peaks with high intensity, indicating better crystallinity. All films consisted mainly of the perovskite phase even thought a small amount of fluorite phase coexisted. The intensities of the SBT peaks are different, the possible reason is different grain size. The major XRD peaks corresponding to (115), (200) and (315) planes were more pronounced than (006) and (0010) lines, which indicated that preferred growth orientation along $c$-axis is suppressed. Two peaks located at about $36.0^{\circ}$ and $57.0^{\circ}$ correspond to fluorite phase. The $\mathrm{Nb}^{5+}$ substitution had very little effect on the crystal orientation of the BiT film. We make attention to BTN as $m$

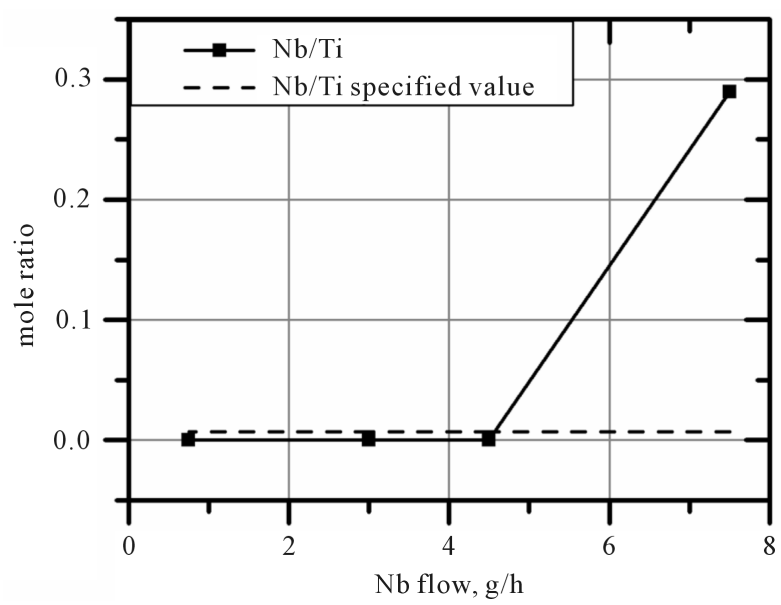

Figure 3. $\mathrm{Nb} / \mathrm{Ti}$ mole ratio of $\mathrm{BNT}$ thin films as a function of the $\mathrm{Nb}$ mass flow. 


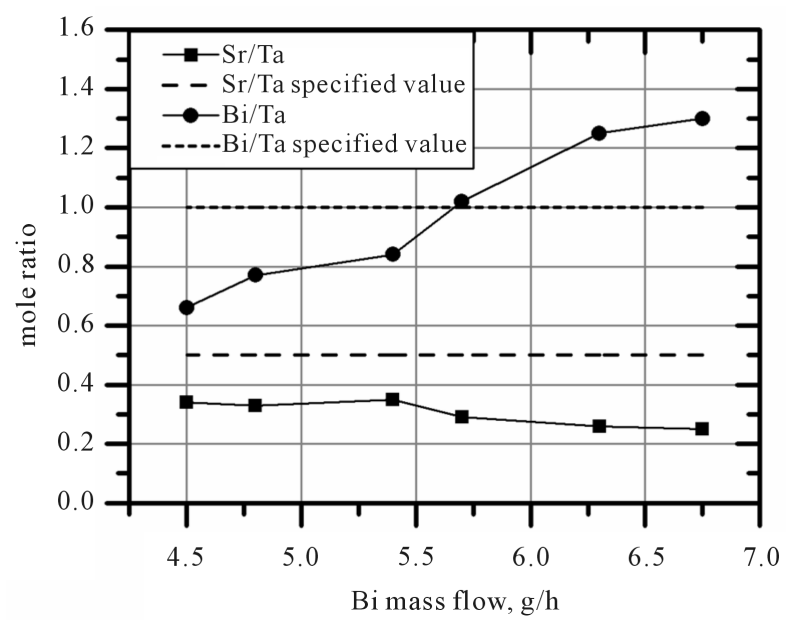

(a)

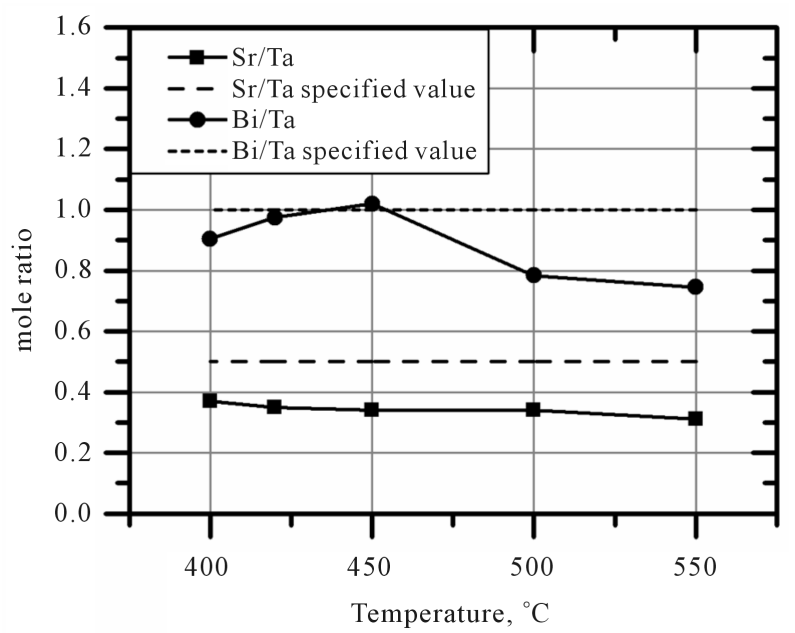

(b)

Figure 4. $\mathrm{Sr} / \mathrm{Ta}$ and $\mathrm{Bi} / \mathrm{Ta}$ mole ratio of SBT thin films as a function of (a) Bi mass flow (b) substrate temperature.

Table 1. Ferroelectric properties of Bi-defficient SBT films.

\begin{tabular}{ccc}
\hline Structure & $\begin{array}{c}2 \cdot \mathrm{P}_{\mathrm{r}}\left(\mu \mathrm{C} / \mathrm{cm}^{2}\right) \\
(500 \mathrm{kV} / \mathrm{cm}\end{array}$ & $\mathrm{E}_{\mathrm{C}}, \mathrm{kV} / \mathrm{cm}$ \\
\hline $\mathrm{Sr}_{0.68} \mathrm{Bi}_{1.3} \mathrm{Ta}_{2}$ & 2.3 & 89.9 \\
$\mathrm{Sr}_{0.5} \mathrm{Bi}_{1.65} \mathrm{Ta}_{2}$ & 3.6 & 84.9 \\
$\mathrm{Sr}_{0.66} \mathrm{Bi}_{1.74} \mathrm{Ta}_{2}$ & 4.6 & 194.0 \\
$\mathrm{Sr}_{0.58} \mathrm{Bi}_{2.2} \mathrm{Ta}_{2}$ & 7.4 & 184.9
\end{tabular}

$=2$ material with the lattice parameter of $a=0.540 \mathrm{~nm}, b=0.545 \mathrm{~nm}, c=2.516 \mathrm{~nm}$ and BIT as $m=3$ material with the lattice parameter of $a=0.541 \mathrm{~nm}, b=0.545 \mathrm{~nm}, c=3.284 \mathrm{~nm}$. We observe only one unit cell of BIT (114) in M2-A and M3-A layers and no peaks considered to BTN (0012) and (0018). At $800^{\circ} \mathrm{C}$ annealing temperature the pyrochlore phase appears and this would impair the ferroelectric properties.

Polarization-electric field (P-E) hysteresis loops were measured to examine the effect in the ferroelectric properties of the combination of the SBT and BTN multilayer with different stacking periodicity under a maximum electric field of $500 \mathrm{kV} / \mathrm{cm}$ (Figure 6). All the films exhibit a well-defined and saturated hysteresis loops. 


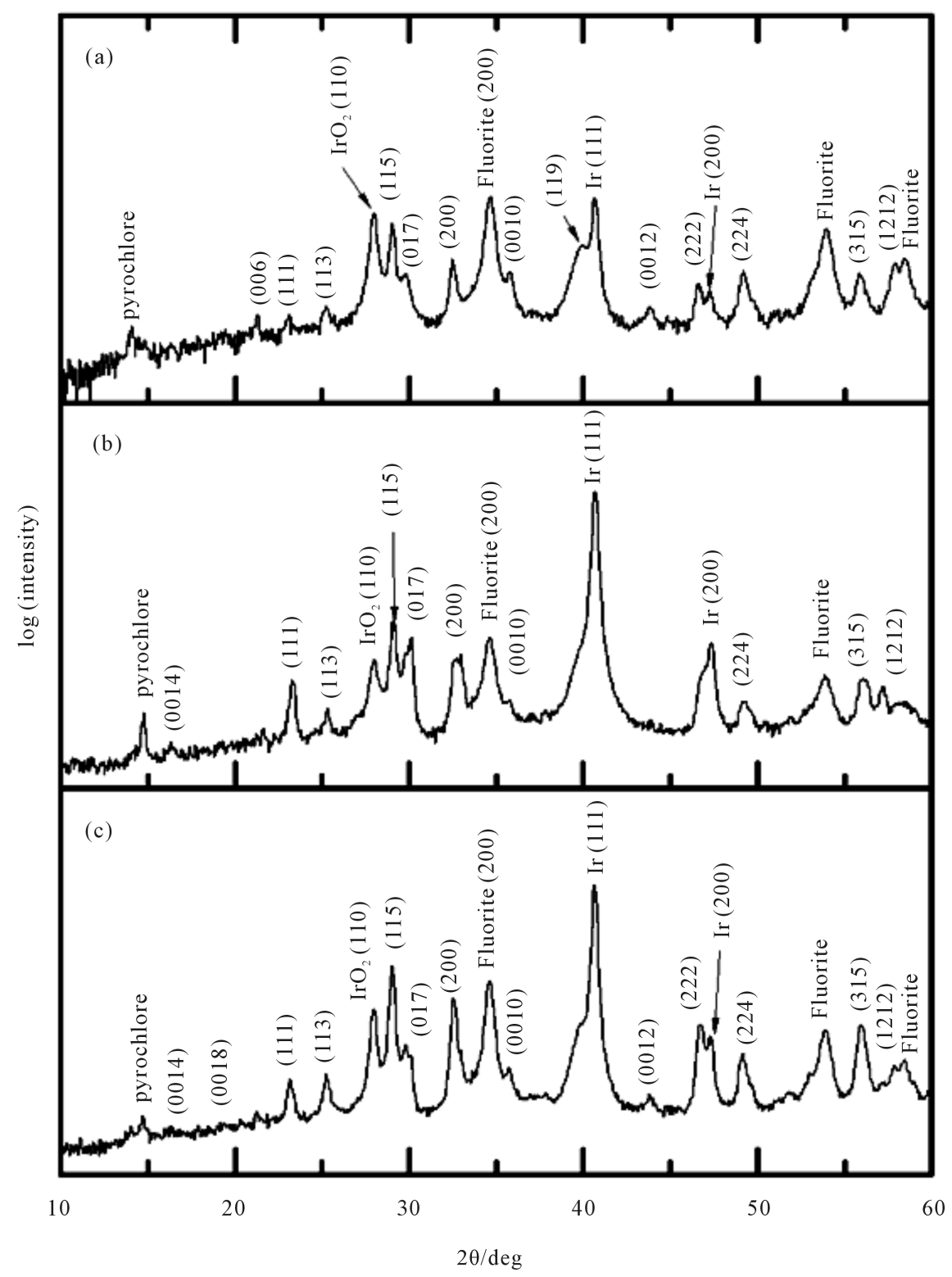

Figure 5. XRD patterns of (a) single SBT, (b) bilayer M2-A and (c) multilayer M3-A annealed at $800^{\circ} \mathrm{C}$ for $30 \mathrm{~min}$.

Figure 6 shows the P-E hysteresis curve measured on the bilayer (M2-A, M2-B), multilayer (M3-A) and the single layer SBT films. The measured remanent polarization values of the bilayer M2-A $\left(\sim 15.4 \mu \mathrm{C} / \mathrm{cm}^{2}\right)$ is comparable with multilayer M3-A $\left(\sim 16.2 \mu \mathrm{C} / \mathrm{cm}^{2}\right)$, higher than M2-B $\left(\sim 9.8 \mu \mathrm{C} / \mathrm{cm}^{2}\right)$ and much higher than that of the single layer SBT $\left(\sim 6.4 \mu \mathrm{C} / \mathrm{cm}^{2}\right)$, which is consistent with other reports [26] [29].

Although, the coercive field of the bilayer (e.g. M2-A, $E_{C}=184 \mathrm{kV} / \mathrm{cm}, \mathrm{M} 2-\mathrm{B}, \mathrm{E}_{\mathrm{C}}=165 \mathrm{kV} / \mathrm{cm}$ ) and multilayer (e.g. M3-A, $\left.E_{C}=230 \mathrm{kV} / \mathrm{cm}\right)$ is higher than that of single SBT $\left(E_{C}=154 \mathrm{kV} / \mathrm{cm}\right)$. The $\mathrm{Nb}^{5+}$ substitution hasn't induced the large inhomogeneity in the thin film due to the close valence of $\mathrm{Nb}^{5+}$ and $\mathrm{Ti}^{4+}$, so $\mathrm{E}_{\mathrm{C}}$ almost no change. The $\mathrm{P}_{\mathrm{r}}$ value and the squareness of the hysteresis loops increased with increasing postannealing temperature (now shown). Both the remanent polarizations $\mathrm{P}_{\mathrm{r}}$ and the coercive electric field $\mathrm{E}_{\mathrm{C}}$ of multilayer M3-A film increase with the increase of annealing temperature up to $800^{\circ} \mathrm{C}$, so at $750^{\circ} \mathrm{C} 2 \cdot \mathrm{P}_{\mathrm{r}}$ values reached 6.8 $\mu \mathrm{C} / \mathrm{cm}^{2}\left(E_{\mathrm{C}}=194 \mathrm{kV} / \mathrm{cm}\right)$ and $16.2 \mu \mathrm{C} / \mathrm{cm}^{2}\left(E_{\mathrm{C}}=229 \mathrm{kV} / \mathrm{cm}\right)$ at $800^{\circ} \mathrm{C}$. The increase of the $\mathrm{P}_{\mathrm{r}}$ and $\mathrm{E}_{\mathrm{C}}$ value with increasing postannealing temperature is mainly due to increase of the crystallinity of the film and decrease 


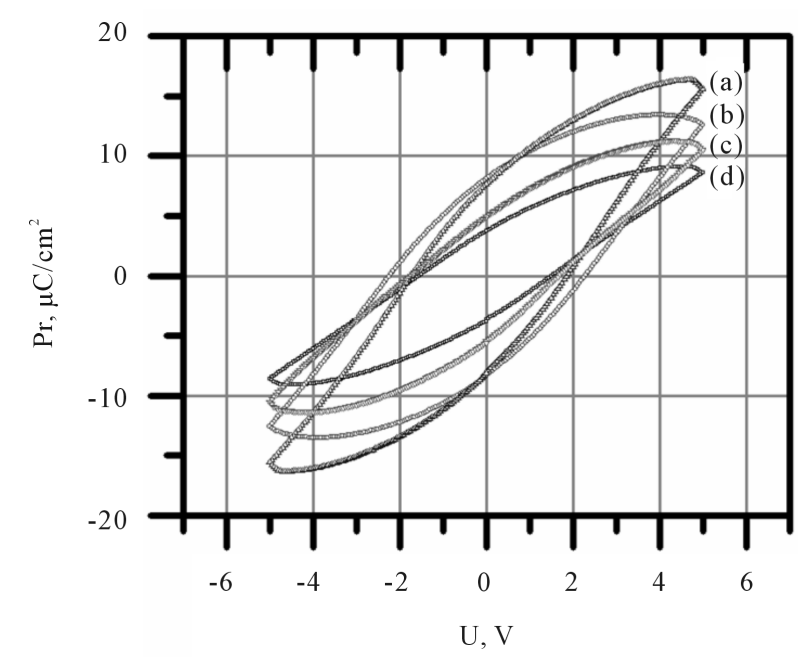

Figure 6. P-E hysteresis loop for (a) multilayer SBT/BTN, (b) bilayer M2-A, (c) bilayer M2-B and (d) single layer SBT thin films at room temperature.

Table 2. Ferroelectric properties of SBT/BTN multilayer films.

\begin{tabular}{ccc}
\hline Structure & $2 \cdot \mathrm{P}_{\mathrm{r}}, \mu \mathrm{C} / \mathrm{cm}^{2}$ & $\mathrm{E}_{\mathrm{C}}, \mathrm{kV} / \mathrm{cm}$ \\
\hline SBT & 6.4 & 154 \\
M2-A (SBT-BTN) & 15.4 & 184 \\
M2-B (BTN-SBT) & 9.8 & 165 \\
M3-A (SBT-BTN-SBT) & 16.2 & 230 \\
\hline
\end{tabular}

of the vacancies of $\mathrm{Bi}$ and oxide ions in films, also reported elsewhere [6] [30]. On the films processed above $700^{\circ} \mathrm{C}$, postannealing markedly increased the capacitor shorting rate, this was attributed to oxidizing of the top Ir layer observed in other reports [30]. Table 2 summarizes the ferroelectric properties of the investigated films. The ferroelectric properties of multilayer thin films are different from that of the pure thin films due to the presence of the interface region. The interface stress plays a significant role for close lattice matched systems [31]. In the case of multilayers, the combining effect of both the layers is reflected in the properties by improving the fatigue and with a high polarization [9]-[14]. In our SBT/BTN multilayer systems, ferroelectric properties are the result of the contributions from both SBT and BTN.

\section{Conclusion}

Multilayer structures with alternated layer of SBT and BTN have been prepared on $\mathrm{Ir} / \mathrm{Ti} / \mathrm{SiO}_{2} / \mathrm{Si}$ substrate using MOCVD technique. On the films processed above $700^{\circ} \mathrm{C}$, postannealing increased the capacitor shorting rate. The multilayer structure exhibited well-defined hysteresis loop, with a higher remanent polarization of $\sim 16.2$ $\mu \mathrm{C} / \mathrm{cm}^{2}$ and a coercive field of $230 \mathrm{kV} / \mathrm{cm}$ under a maximum electric field of $500 \mathrm{kV} / \mathrm{cm}$ and $100 \mathrm{~Hz}$. These results are considerably better compared to SBT single layer samples. The results reveal that the multilayer structure is a promising material combination for ferroelectric memory applications.

\section{References}

[1] Paz de Araujo, C.A., Cuchiaro, J.D., Mcmillan, L.D., Scott, M.C. and Scott, J.F. (1995) Fatigue-Free Ferroelectric Capacitors with Platinum Electrodes. Letters toNature, 374, 627-629. http://dx.doi.org/10.1038/374627a0

[2] Park, B.H., Kang, B.S., Bu, S.D., Noh, T.W., Lee, J. and Joe, W. (1999) Lanthanum-Substituted Bismuth Titanate for Use in Non-Volatile Memories. Letters to Nature, 401, 682-684. http://dx.doi.org/10.1038/44352

[3] Watanabe, T., Kojima, T, Sakai, T., Funakubo, H., Osada, M., Noguchi, Y. and Miyayama, M. (2002) Large Remanent 
Polarization of $\mathrm{Bi}_{4} \mathrm{Ti}_{3} \mathrm{O}_{12}$-Based Thin Films Modified by the Site Engineering Technique. Journal of Applied Physics, 92, 1518-1521. http://dx.doi.org/10.1063/1.1491594

[4] Kojima, T., Sakai, T., Watanabe T., Funakubo, H., Saito, K. and Osada, M. (2002) Large Rmanent Polarization of $(\mathrm{Bi}, \mathrm{Nd})_{4} \mathrm{Ti}_{3} \mathrm{O}_{12}$ Epitaxial Thin Films Grown by Metalorganic Chemical Vapor Deposition. Applied Physics Letters, 80, 2746. http://dx.doi.org/10.1063/1.1468914

[5] Bao, Z.H., Yao, Y.Y., Zhu, J.S. and Wang, Y.N. (2002) Study on Ferroelectric and Dielectric Properties of Niobium Doped $\mathrm{Bi}_{4} \mathrm{Ti}_{3} \mathrm{O}_{12}$ Ceramics and Thin Films Preparedby PLD Method. Materials Letters, 56, 861-866. http://dx.doi.org/10.1016/S0167-577X(02)00628-6

[6] Noguchi, Y. and Miyayama, M. (2001) Large Remanent Polarization of Vanadium-Doped $\mathrm{Bi}_{4} \mathrm{Ti}_{3} \mathrm{O}_{12}$. Applied Physics Letters, 78, 1903. http://dx.doi.org/10.1063/1.1357215

[7] Shulman, H.S., Testorf, M., Damjanovic, D. and Setter, N.J. (1995) Microstructure, Electrical Conductivity, and Piezoelectric Properties of Bismuth Titanate. Journal of the American Ceramic Society, 79, 3124-3228.. http://dx.doi.org/10.1111/j.1151-2916.1996.tb08086.x

[8] Villegas, M., Caballero, A.C., Moure, C., Duran, P. and Fernandez, J.F. (1999) Factros Affecting The Electrical Conductivity of Donor-Doped $\mathrm{Bi}_{4} \mathrm{Ti}_{3} \mathrm{O}_{12}$ PiezoelectricCeramics. Journal of the American Ceramic Society, 82, 2411-2416. http://dx.doi.org/10.1111/j.1151-2916.1999.tb02098.x

[9] Shibuya, A., Noda, M., Okuyama, M., Fujisawa, H. and Shimizu, M. (2003) Natural-Superlattice-Structured $\mathrm{Bi}_{4} \mathrm{Ti}_{3} \mathrm{O}_{12}-$ $\mathrm{SrBi}_{4} \mathrm{Ti}_{4} \mathrm{O}_{15}$ Ferroelectric Thin Films. Applied Physics Letters, 82, 784. http://dx.doi.org/10.1063/1.1543248

[10] Kikuchi, T., Watanabe, A. and Uchida, K. (1977) A Family of Mixed-Layer Type Bismuth Compounds. Materials Research Bulletin, 12, 299-304. http://dx.doi.org/10.1016/0025-5408(77)90148-9

[11] Noguchi, Y., Miyayama, M. and Kudo, T. (2000) Ferroelectric Properties of Intergrowth $\mathrm{Bi}_{4} \mathrm{Ti}_{3} \mathrm{O}_{12}-\mathrm{SrBi}_{4} \mathrm{Ti}_{4} \mathrm{O}_{15} \mathrm{Ce}-$ ramics. Applied Physics Letters, 77, 3639. http://dx.doi.org/10.1063/1.1328366

[12] Shibuya, A., Noda, M., Okuyama, M. and Saito, K. (2004) Metallic $\mathrm{LaTiO}_{3} / \mathrm{SrTiO}_{3}$ Superlattice Films on the $\mathrm{SrTiO}_{3}$ (100) Surface. Japanese Journal of Applied Physics, 43, 1178-1180. http://dx.doi.org/10.1143/JJAP.43.L1178

[13] Shibuya, A., Ikemori, S., Wu, W.B., Noda, M. and Okuyama, M. (2003) Preparation and Basic Properties of Ferroelectric Thin Films Having a Superlattice Structure of $2 \mathrm{Bi}^{3} \mathrm{TiNbO}^{9}$ Units- $1 \mathrm{Bi}^{4} \mathrm{Ti}^{3} \mathrm{O}^{12}$ Unit. Applied Physics Letters, 83, 1411-1413. http://dx.doi.org/10.1063/1.1604171

[14] Sakamoto, W., Imada, K., Shimura, T. and Yogo, T. (2005) Synthesis and Properties of Intergrown $\mathrm{Bi}_{4} \mathrm{Ti}_{3} \mathrm{O}_{12}-$ $\mathrm{SrBi}_{4} \mathrm{Ti}_{4} \mathrm{O}_{15}$ Ferroelectric Thin Films by Chemical Solution Deposition. Japanese Journal of Applied Physics, 44, $6952-$ 6956. http://dx.doi.org/10.1143/JJAP.44.6952

[15] Ortega, N., Bhattacharya, P. and Katiyar, R.S. (2006) Enhanced Ferroelectric Properties of Multilayer $\mathrm{SrBi}_{2} \mathrm{Ta}_{2} \mathrm{O}_{9} /$ $\mathrm{SrBi}_{2} \mathrm{Nb}_{2} \mathrm{O}_{9}$ Thinfilms for NVRAM Applications. Materials Science and Engineering B, 130, 36-40. http://dx.doi.org/10.1016/j.mseb.2006.02.006

[16] Hyeon, J.-Y., Lisker, M., Silinskas, M., Burte, E.P. and Edelmann, F.T. (2005) Liquid-Delivery MOCVD of Strontium Bismuth Tantale Thin Films Using $\mathrm{Sr}\left[\mathrm{Ta}\left(\mathrm{OC}_{2} \mathrm{H}_{5}\right)_{5}\left(\mathrm{OCH}_{2} \mathrm{CH}_{2} \mathrm{OCH}_{3}\right)\right]_{2}$ and Liquid $\mathrm{Bi}\left(\mathrm{CH}_{2} \mathrm{CH}=\mathrm{CH}_{2}\right)_{3}$ as Precursors as Precursors. Chemical Vapor Deposition, 11, 213-218. http://dx.doi.org/10.1002/cvde.200406335

[17] Ritterhaus, Y., Hur'yeva, T., Lisker, M. and Burte, E.P. (2007) Iridium Thin Films Deposited by Liquid Delivery MOCVD Using $\operatorname{Ir}(\mathrm{EtCp})(1,5-\mathrm{COD})$ with Toluene Solvent. Chemical Vapor Deposition, 13, 698-704. http://dx.doi.org/10.1002/cvde.200706630

[18] Lisker, M., Hur'yeva, T., Ritterhaus, Y. and Burte, E.P. (2007) Effect of Annealing in Oxygen Atmosphere on Morphological and Electrical Properties of Iridium and Ruthenium Thin Films Prepared by Liquid Delivery MOCVD. Surface and Coatings Technology, 201, 9294-9298. http://dx.doi.org/10.1016/j.surfcoat.2007.04.078

[19] Yang, B., Zhang, X.J. and Zhang, S.T. (2001) Bismuth-Layered-Ferroelectric $\mathrm{BI}_{3} \mathrm{TINBO}_{9}$ Thin Films Grown by Pulsed Laser Deposition. Ferroelectrics, 252, 493-500. http://dx.doi.org/10.1080/00150190108016267

[20] Yang, B., Zhang, X.J., Zhang, S.T., Chen, X.Y., Wu, Z.C., Chen, Y.F., Zhu, Y.Y., Liu, Z.G. and Ming, N.B. (2001) In Situ Electrical-Field-Induced Growth and Properties of $\mathrm{Bi}_{3} \mathrm{TiNbO}_{9}$ Ferroelectric Thin Films. Applied Physics Letters, 79, 4559. http://dx.doi.org/10.1063/1.1430023

[21] Zhu, J., Zhang, X., Zhu, Y. and Desu, S.B. (1998) Size Effects of 0.8 $\mathrm{SrBi}_{2} \mathrm{Ta}_{2} \mathrm{O}_{9}-0.2 \mathrm{Bi}_{3} \mathrm{TiNbO}_{9}$ Thin Films. Journal of AppliedPhysics, 83, 1610. http://dx.doi.org/10.1063/1.366872

[22] Perez, W., Ching-Prado, E., Dobal, P.S., Reynes-Figueroa, A., Katiyar, R.S., Tirumala, S. and Desu, S.B. (1999) Micro-Raman Study of $\mathrm{SrBi}_{2} \mathrm{Ta}_{2} \mathrm{O}_{9}-\mathrm{Bi}_{3} \mathrm{TiNbO}_{9}$ Thin Films. Proceedings of Materials Research Society, 541, 274.

[23] Ching-Prado, E., Pérez, W., Dobal, P.S., Katiyar, R.S., Tirumala, S. and Desu, S.B. (2000) A Structural Study of $\mathrm{SrBi}_{2} \mathrm{Ta}_{2} \mathrm{O}_{9}-\mathrm{Bi}_{3} \mathrm{TiNbO}_{9}$ Ferroelectric Thin Films. Proceedings of Materials Research Society, 596, 173. 
http://dx.doi.org/10.1557/PROC-596-173

[24] Silinskas, M., Lisker, M., Kalkofen, B., Matichyn, S. and Burte, E.P. (2004) Deposition Kinetics of MOCVD of Strontium Bismuth Tantalate Thin Films. Lithuanian Journal of Physics, 44, 375-379. http://dx.doi.org/10.3952/lithjphys.44508

[25] Lisker, M., Silinskas, M., Kalkofen, B. and Burte, E.P. (2005) Liquid-Delivery MOCVD of SBT Thin Films Using Novel Bismuth Precursors. Proceedings of the EUROCVD, Bochum, 5-9 September 2005, 881-888.

[26] Song, C.H., Lia, W., Maa, J., Gua, J., Yaoa, Y.Y., Fenga, Y., Lua, X.M., Zhua, J.S., Wanga, Y.N., Chanb, W.L.H. and Choy, C.L. (2004) Ferroelectric Properties of $\mathrm{Bi}_{3.25-x / 3} \mathrm{La}_{0.75} \mathrm{Ti}_{3-x} \mathrm{Nb}_{x} \mathrm{O}_{12}$ Films Prepared by Pulsed Laser Deposition. Solid State Communications, 129, 775-780. http://dx.doi.org/10.1016/j.ssc.2003.12.030

[27] Li, Y.B., Zhang, S., Fei, W.D., Gan, Z.H. and Mhaisalkar, S. (2007) Formation and Stability of Pyrochlore in Sputtered SBT Thin Films. Advances in Applied Ceramics, 106, 180-185. http://dx.doi.org/10.1179/174367607X178139

[28] Boyle, T.J., Buchheit, C.D. and Rodriguez, M.A. (1996) Formation of $\mathrm{SrBi}_{2} \mathrm{Ta}_{2} \mathrm{O}_{9}$-Part I: Synthesis and Characterization of a Novel "Sol-Gel" Solution for Production of Ferroelectric $\mathrm{SrBi}_{2} \mathrm{Ta}_{2} \mathrm{O}_{9}$ Thin Films. Journal of Materials Research, 11, 2274-2281. http://dx.doi.org/10.1557/JMR.1996.0289

[29] Kim, J.K., Kim, J., Song, T.K. and Kim, S.S. (2002) Effects of Niobium Doping on Microstructures and Ferroelectric Properties of Bismuth Titanate Ferroelectric Thin Films. Thin Solid Films, 419, 225-229. http://dx.doi.org/10.1016/S0040-6090(02)00550-3

[30] Lisker, M., Hur'yeva, T., Ritterhaus, Y. and Burte, E.P. (2009) Effect of Annealing in Oxygen Atmosphere on Morphological and Electrical Properties of Iridium and Ruthenium Thin Films Prepared by Liquid Delivery MOCVD. Surface and Coatings Technology, 201, 9294-9298. http://dx.doi.org/10.1016/j.surfcoat.2007.04.078

[31] Ge, S.B., Ning, Z.Y., Dong, Z.G. and Shen, M.R. (2002) Investigation on Dielectric Properties of Polycrystalline BT/ST Multilayer Thin Films. Journal of Physics D: Applied Physics, 35, 906-910. http://dx.doi.org/10.1088/0022-3727/35/9/311 